\title{
Perceived Development of Sustainable Agriculture
}

UDK: $631(045)$

\author{
Maja Klun \\ University of Ljubljana, Faculty of Administration \\ maja.klun@fu.uni-lj.si
}

Renata Slabe Erker

Institute for Economic Research

erkerr@ier.si

\section{ABSTRACT}

Within the concept of sustainable agriculture, the two fields of administration of the Ministry of Agriculture and the Environment come face to face, resulting in a number of social implications. In order to provide assistance in the shaping, execution and assessment of sustainable activities, in this article we analyse the attitude of the public and farmers towards sustainable development in agriculture. The results reveal that in Slovenia, sustainable agriculture has support not only on the level of declarations, but also among the public. Statistically significant differences between the general public and farmers can be noted in the groups' respective understandings of the sustainable advancement of agriculture in the field of the environment. In parallel to this, a rift can be noted between support for sustainable agriculture in principle and in practice. For this reason, it would be wise to consider shifting the focus of agricultural policy measures from environmental sustainability to social sustainability and the survival of farmers, along with an emphasis on positive environmental information regarding Slovenian farmers.

Key words: sustainable development of agriculture, perceptions, public, farmers, indicators of sustainable agriculture

JEL: Q18, Q01

\section{Introduction}

Sustainable development, of which sustainable agriculture constitutes a key part, is one of the main long-term priority objectives of the European Union in its focus on enhancing the quality of life of people. Through its economic, environmental and social role, the European Union is addressing the challenges laid out in the Lisbon Strategy (2000); in a diverse country such

Klun, M. \& Slabe Erker, R. (2012). Perceived Development of Sustainable Agriculture. Uprava/Administration X(2), 49-70. 
as Slovenia, the fundamental objective of the Strategy - new, quality jobs and enhanced competitiveness - can be fulfilled through the development of the countryside. In this sense, sustainable development not only creates, directly and indirectly, employment on the local level and beyond in synergy with other economic activities, but is also a source of healthy, safe food, a basic condition of the preservation of biological and regional diversity, a counterweight to population decline in rural areas, a corner stone of natural tourism, and a factor that enables the implementation of other environmental and social functions of space which enhance the quality of life, such as ecosystem functions, aesthetic functions, cultural functions and recreational functions.

On the level of declarations, the European Union has decided on sustainable development and, in this framework, for sustainable agriculture. This is why state and international institutions such as the UN Food and Agriculture Organisation (FAO) and Ministries whose work intersects with the field of agriculture are encouraging farmers to implement sustainable agricultural practices and encouraging the public to embrace these practices. A condition for establishing this type of relationship between the public and agriculture is the trust and knowledge, generated in advance, that these practices do in fact offer real benefits (Tathdil et al., 2009).

In the future, the Common Agricultural Policy (European Commission, 2012) will have to be sustainability-oriented, balanced, goal-oriented, effective and responsible. For decades, agriculture has been losing its economic importance (which is expressed, among other things, in its share of the GDP), while at the same time maintaining its spatial and social dimensions; furthermore, the basic cultivation function of agriculture, that is, the role of food as a strategic commodity, is once again coming to the fore. It follows that the key challenges of the new agricultural policy in the next programme period are food safety, the sustainable management of natural resources and balanced territorial development.

The level of legitimacy and acceptability of a social objective - in this case, sustainable agriculture - increases with the openness of public administration, in the sense that the latter knows how to listen to citizens' opinions regarding the state and execution of policy. This is why it is important to know what the attitude of the public is towards sustainable development in agriculture, how the public interprets sustainability and what meaning and importance it attaches to it. Furthermore, it is important to identify factors that have an impact on these perceptions. It is very difficult to effectively and responsibly execute a policy without sufficient public support and/or if the policy in question is difficult to understand and insufficiently promoted. In democratic systems, the bodies of state generally wish to gauge the public's reaction to the current state/decisions (and also to the expert basis for their decisions), even if the inclusion or impact of the public in/on public-political decisions can only be expressed to a very limited extent in the ultimate political will. This article aims to fill the void in empirical research of public opinion on sustainable 
agriculture in Slovenia and to provide an analysis of public opinion vis-à-vis the actual situation as revealed by indicators of sustainable agriculture.

For the time being, there is no one uniform definition of sustainable agriculture. It is more of a philosophy or a way of farming and, at the same time, a way of life, within which a variety of interpretations and understandings are possible. Because the term "sustainability« applies to a balanced emphasis on environmental, social and economic components of development, the same should also hold true for sustainable agriculture. And yet, to take one example, the interpretation of sustainable development found in Article 15 of the Agriculture Act of the Republic of Slovenia (Official Gazette of the Republic of Slovenia, no. 45/2008) is limited to the environmental component: "Sustainable agriculture preserves the biological diversity of plant and animal life and preserves the soil and its fertility while protecting the natural conditions of life on the ground, in the water and in the air." Such an interpretation would be more in line with »ecological« agriculture, a concept which places emphasis on environmental (ecological) sustainability.

Although agriculture is primarily linked to climate, soil, land, water, woodlands, biological diversity, the cultivation of arable land, and livestock, one cannot overlook its connection to farmers, rural communities, poverty and other social issues. It follows that the sustainable growth of agriculture not only impacts the production of food and the use of natural resources, but is also important for the well-being of people in the agricultural community and for society as a whole. In this sense it is necessary to expand our perspective on sustainable agriculture.

Ikerd (1996) offers a broader definition of sustainable development, which sees it as environmentally friendly or harmless from the standpoint of the use of natural resources, economically justifiable, socially supported and competitive. Plut (2004) offers a similar, holistic interpretation of sustainability. Sustainable development demands a shift towards economic advancement in the sense of limiting environmental impacts, and at the same time must strive to enable the fulfilment of the needs of current generations while not presenting a threat to the life of future generations (of both people and flora and fauna). In terms of the sustainable development of agriculture, sustainable development therefore indicates an attitude towards nature and the self-renewability of the latter and an attitude towards man and his psychic and physical capabilities (Plut, 2004).

The US government offers a very comprehensive legal definition of sustainable agriculture: »An integrated system of plant and animal production practices having a site-specific application that will, over the long term, satisfy: (i) human food and fiber needs; (ii) enhance environmental quality and the natural resource base upon which the agricultural economy depends; (iii) make the most efficient use of nonrenewable resources and on-farm resources and integrate, where appropriate, natural biological cycles and controls; (iv) 
Maja Klun, Renata Slabe Erker

sustain the economic viability of farm operations; and (v) enhance the quality of life for farmers and society as a whole« (Public Law 101-624, Title XVI, Subtitle A, Section 1683).

In our research, we wished to gauge how broadly the general public and farmers in Slovenia understand sustainable agriculture. Furthermore, we were interested in assessing how they rank the importance of the development of sustainable agriculture through the use of various functions and objectives of agricultural policy and determining whether deviations occur between the opinion of the general public on the one hand and the opinion of farmers on the other regarding how important the sustainable development of agriculture actually is. The method of primary data analysis was used in the research. Data was obtained using surveys conducted among the two target groups. The results of the public opinion research were then compared with the actual situation, that is, with indicators of the sustainable agriculture.

The article is structured in such a way that it first presents an overview of similar research conducted in Slovenia and in other countries. This is followed by a presentation of the methodology and survey forms used and the results of the research. The article concludes with the key findings, implications for practice and a discussion.

\section{An overview of research conducted to date}

Despite the great emphasis placed on policies for encouraging sustainable agriculture, in practice very little research on how sustainable agriculture is understood by different target groups has been conducted. Gauging public perception and the factors that impact public opinion should be an obligatory first step in the development of programmes for informing the public about the importance of sustainable agriculture in a given place and society (Tathdil et al., 2009).

Public opinion on sustainable agriculture is one of the things that the Eurobarometer tracks on the level of the EU. The results reveal that EU citizens view providing social stability for farmers as the most important aspect of sustainable agricultural policy (Special Eurobarometer, 2008), which is in line with the results of our research on a sample of the population of farmers (see below).

Partial studies on the perception of sustainable agriculture have been undertaken both in Europe and elsewhere, as this field is of interest to a number of social spheres (politics, science, the economy, etc.). These research undertakings focused on various factors. More comprehensive research very similar to the research on the situation in Slovenia presented below has been conducted in Turkey (Tathdil et al., 2009). The basic purpose of the Turkish study was to provide a quantitative assessment of the understanding of sustainable development among farmers and to determine how various socio-economic 
factors and the information available to farmers impact this understanding. The socio-economic characteristics encompassed the agricultural system, the size of the farm, inclusion in co-operatives and other organisations in the local community, age, education and the farmer's income. The component of access to information and searching information included the use of mass media (newspapers, radio, television), internet use, travel and participation in agricultural conferences. The results of the study show higher socioeconomic status and greater access to information mean that farmers attach greater importance to sustainable agriculture. Therefore if policy shapers and other competent organisations were to focus on demographically targeted information measures, they would meet with greater success in their efforts to steer farmers towards embracing sustainable agriculture.

In his research, Aerni (2009) warns that public debates on sustainable agriculture are usually shaped by the dominant political interest groups, which simultaneously contribute to and respond to the shaping of public opinion. He assessed the extent to which the attitude of these groups is linked to the public's opinion about sustainable agriculture and how these understandings differ between countries with different agricultural policies. Two research projects focusing on perceptions of sustainable agriculture were carried out, one in Switzerland and one in New Zealand. Analysis of the data showed that between citizens of the two countries there exist considerable differences in how sustainability is understood. While in Switzerland citizens felt that agriculture in Switzerland is already considerably sustainability-oriented, the respondents in New Zealand felt for the most part that certain economic and technological changes need to be implemented in order to make agriculture more sustainability-oriented. The results accord with the fact that in Switzerland, agricultural policy is more defensive, while the approach in New Zealand is more linked to that country's sustainable agricultural policy, which is in turn linked to the competitiveness of the economy as a whole.

Studies conducted in developing countries are very specific regarding the inclusion of factors that impact the perception of the sustainable development of agriculture. A common point of all those studies is that they reveal the public's sensitivity to reducing poverty, achieving the sustainable use of natural resources, controlling erosion and soil degradation, the correct use of fertilisers and pesticides and investments in research and expanding services (Bhutto \& Bazmi, 2007). For example, Rao \& Hall (2003) conducted a study in India (for a similar study from Bangladesh see Rahman, 2003) which showed that the reasons for the barriers to reducing poverty and implementing sustainable development in agriculture lie in either a lack of state funds or a negative perception of modern agricultural technologies among farmers. Farmers believe that modern technology has harmful effects on the environment such as reduced fertility of the soil and harmful effects on health and lead to a greater occurrence of diseases in plants (Tathdil et 
Maja Klun, Renata Slabe Erker

al., 2009). A similar situation exists in other third-world countries (see, for example, Taylor et al., 1993 regarding Malaysia).

While the above mentioned countries face a lack of recognition of the concept of sustainable agriculture, studies conducted in the US reveal different problems. Alonge \& Marting (1995) found that, on the one hand, farmers are more aware of and acquainted with the negative environmental and social effects of conventional agriculture; on the other hand, this is not making an impact on the acceptance and implementation of sustainable agricultural practices. Attempts to explain the low rate of implementation of sustainable agricultural practices have been numerous and diverse. This phenomenon is often explained, for example, through a desire for increased productivity through the use of machines which make a negative impact on the environment (Swanson et al., 1986; Naper et al., 1984). Studies in the US have examined the many possible impacts on the acceptance of the new method of farming, taking into account economic, social, physical and technical aspects of agriculture. Rao \& Rogers (2006) stressed the importance of the following factors: the perception of risk and profitability, certainty and uncertainty regarding the acceptance of sustainable agriculture; the volume of the required information; and attitude towards sustainable agriculture. Certain influential factors were also identified: demographic factors, knowledge, awareness, group mentality, technological characteristics and access to information. The results reveal a positive and strong correlation between age, experience in farming, education and socio-economic status, intensiveness of cultivation, motivation and innovation, and the use of information, and the acceptance of sustainable agriculture (Hosseini et al., 2011).

In Slovenia, Juvančič \& Slabe Erker (2006) dealt with the question of the extent to which political instruments are harmonised with the public interest in the field of multi-purpose farming. The results of the research revealed that broad political support for the sustainable management of arable land and the preservation of the countryside in Slovenia is generally in accordance with the public's preferences. Conversely, the public gives high priority to the aspect of safe and quality food, while political support for this aspect is low.

\section{Methodology}

The data set used in the research was obtained through a survey conducted in the framework of the "Parameters of the Sustainable Development of Agriculture« research project (2012). Two different survey forms were used to obtain the data; the forms differ based on whether they were completed by people who have a farm at home or the general public. The observed units from the first and the second survey form are understood as two independent samples, the »public« sample and the »farmers« sample.

To test the hypothesis that the attitudes of the public on the one hand and of farmers on the other towards sustainable agriculture in Slovenia do not

54 Administration, Vol. X, No. 2/1012 
differ, a Mann-Whitney non-parametric test for two independent samples was used. This test is equivalent to a t-test and is used when dealing with descriptive variables on an ordinal scale. Rank values are used to calculate the test statistics. This is why numeric variables are converted to ranks so that the lowest values are assigned the lowest rank. The Mann-Whitney test is based on the test statistic $U$, defined for the group $i$, whereby: (Mann \& Whitney, 1947)

$$
U_{i}=n_{1} n_{2}+\frac{n_{1}\left(n_{1}+1\right)}{2}-R_{i}
$$

with $R_{i}$ being the total of ranks of the group $i$.

\subsection{Survey form}

To facilitate easier statistical data processing, the questions used in the survey were of the closed type and had pre-defined answers. The survey forms for the general public and for farmers encompass 5 content questions with multiple statements, whereby the respondent was asked the degree to which he/she does or does not agree with the statement in question; responses were given on a scale of 1 to 5 . Therefore only the perception of the respondents was assessed, as they only gave a mark or grade to each statement. The sixth and final question contains general demographic questions about the respondent: gender, age, education, region where the respondent lives. The survey form completed by the target group of farmers also contains two additional content questions and two additional demographic questions pertaining to the size of the farm in terms of cadastral income and the predominant orientation of the farm.

We wished to use the survey form to assess which of the highlighted, broadly defined contents best characterises sustainable agriculture in the opinion of the respondents; how high a priority the respondents attach to sustainable development in agriculture as opposed to other areas of society; and the importance of certain functions or objectives of agriculture. In the next set of questions, the respondents assessed the developmental component of sustainable agriculture. They rated the development of agriculture in Slovenia in the past ten years in terms of the provision of food, enabling the sustenance of farmers and environmental preservation and evaluated individual reasons behind the developmental path they had chosen.

The surveys were conducted from November 2011 to the end of February 2012. A random sample of people was selected, whereby efforts were made to ensure that the respondents were suitably distributed in terms of gender, age, education and region, and also in terms of farm size and farm activities in the case of respondents to the survey for the farmers target group. The selection of units for the sample included people who were willing to participate in the survey. The survey was conducted in person. 
Maja Klun, Renata Slabe Erker

507 survey forms were completed for the general public and 329 survey forms were completed for the farmers group, for a total of 836 survey forms. Among the survey forms completed for the general public group, it was found that five forms were not completed in their entirety; these forms were not included in the analysis. The same number of incomplete forms was found among the survey forms for the farmers group.

\subsection{Descriptive statistics}

826 valid observations are available in our database (hereinafter the sample). Most of the respondents (about a third) from the "public sample, and about a fourth of the respondents from the "farmers s sample come from the Central Slovene region. The second most represented region in the survey is Southeast Slovenia. The structure of the respondents by region matches the structure of the population of Slovenia by region. Just under $80 \%$ of the respondents in each sample were between the ages of 24 and 64. In the population of Slovenia this broad age category is represented by a share of two-thirds; persons over 64 years of age represent about $20 \%$ of the population, and young people about $8 \%$. This reveals a problem in our sample from the standpoint of age structure, which was a result of the fact that older people did not wish to respond to the survey. Women are slightly more represented in the "public sample than in the population, where they account for $51 \%$ of the population. They made up only a little more than $40 \%$ of the respondents in the »farmers « sample. This response was to be expected for the surveys conducted among farmers. Higher and vocational education were prevalent among respondents from the "public sample, with more than half the respondents falling in these categories (compared to $20 \%$ in the population); $31.3 \%$ of the respondents had a secondary education (compared to $32 \%$ in the population), followed by $11 \%$ with a Masters or a Doctorate and $3.4 \%$ with a primary education (compared to $20 \%$ in the population). The above-average share of respondents with a higher or vocational education relative to the general population is a result of the fact that people with a primary education did not wish to complete the survey. In the "farmers" sample, secondary education predominates, with approximately half the respondents falling in this category; a little over a third of the respondents had a higher or vocational education. In light of the noted differences in the demographic characteristics of the sample, we also checked any differences in individual answers in terms of these characteristics; it was found that the answers do not vary to a statistically significant degree among respondents when cross-checked with the categories of gender, age, education or region of residence. 
Table 1: Socio-economic characteristics of the sample of respondents

\begin{tabular}{|l|l|l|l|l|}
\hline & \multicolumn{2}{|c|}{ General public (N=502) } & \multicolumn{2}{c|}{ Farm households (N=324) } \\
\hline Variable & $\begin{array}{l}\text { 1st most } \\
\text { frequent reply }\end{array}$ & $\begin{array}{l}\text { 2nd most } \\
\text { frequent reply }\end{array}$ & $\begin{array}{l}\text { 1st most } \\
\text { frequent reply }\end{array}$ & $\begin{array}{l}\text { 2nd most } \\
\text { frequent reply }\end{array}$ \\
\hline Region & $\begin{array}{l}\text { Central Slovenia } \\
(33.5 \%)\end{array}$ & $\begin{array}{l}\text { Southeast } \\
(13.1 \%)\end{array}$ & $\begin{array}{l}\text { Central Slovenia } \\
(25.9 \%)\end{array}$ & $\begin{array}{l}\text { Southeast } \\
(16 \%)\end{array}$ \\
\hline Age category & $24-44(56.6 \%)$ & $44-64(21.9 \%)$ & $44-64(40.5 \%)$ & 24-44 (40.1\%) \\
\hline Gender & Female (61.8\%) & Male (35.7\%) & Male (56.5\%) & Female (43.5\%) \\
\hline Education & $\begin{array}{l}\text { Higher and } \\
\text { vocational } \\
(52 \%)\end{array}$ & $\begin{array}{l}\text { Secondary } \\
(31.1 \%)\end{array}$ & $\begin{array}{l}\text { Secondary } \\
(50.2 \%)\end{array}$ & $\begin{array}{l}\text { Higher and } \\
\text { vocational } \\
(36.1 \%)\end{array}$ \\
\hline
\end{tabular}

In the »farmers« sample, farms with a cadastral income of between $€ 1000$ and $€ 2500$ predominate, followed by the category of farms with a cadastral income of between $€ 500$ and $€ 1000 ; 18.1 \%$ of the respondents reported farms with a cadastral income in the $€ 2500-€ 7500$ range, and $15 \%$ reported farms with a cadastral income of between $€ 200$ and $€ 500$; the least represented category was farms with a cadastral income in excess of $€ 7500$ (8\%). In terms of the main activity at the farm, mixed farms predominate, followed by farms where animal husbandry is the main activity (33\%); $9.4 \%$ of farms have a predominant emphasis on arable farming, and permanent crops were the predominant activity at the farms of $8 \%$ of the respondents. Compared to the population, our sample had more mixed farms and fewer farms focused on arable farming. Data from the Statistical Office of the Republic of Slovenia shows that a little over $56 \%$ of farms in Slovenia focus on animal husbandry, with $22 \%$ of farms focusing on arable farming. Differences in responses were cross-checked using these characteristics and no statistically significant differences were found.

\section{Results}

\subsection{How the general public and farmers understand sustainable agriculture}

High average marks for all statements regarding what best characterises sustainable agriculture and the results of a non-parametric $\chi^{2}$ test for each statement, which confirms statistically significant differences between the observed and expected frequencies $(p=0.000)$, prove that the public and farmers generally have a broad understanding of and attach the same degree of importance to all aspects of agricultural sustainability - environmental aspects, social aspects and economic aspects. Average marks for the statements differ only slightly between the two groups of respondents (cf. Graph 1). 
Maja Klun, Renata Slabe Erker

Graph 1: A comparison of average marks given by the public and farmers on what best characterises sustainable agriculture

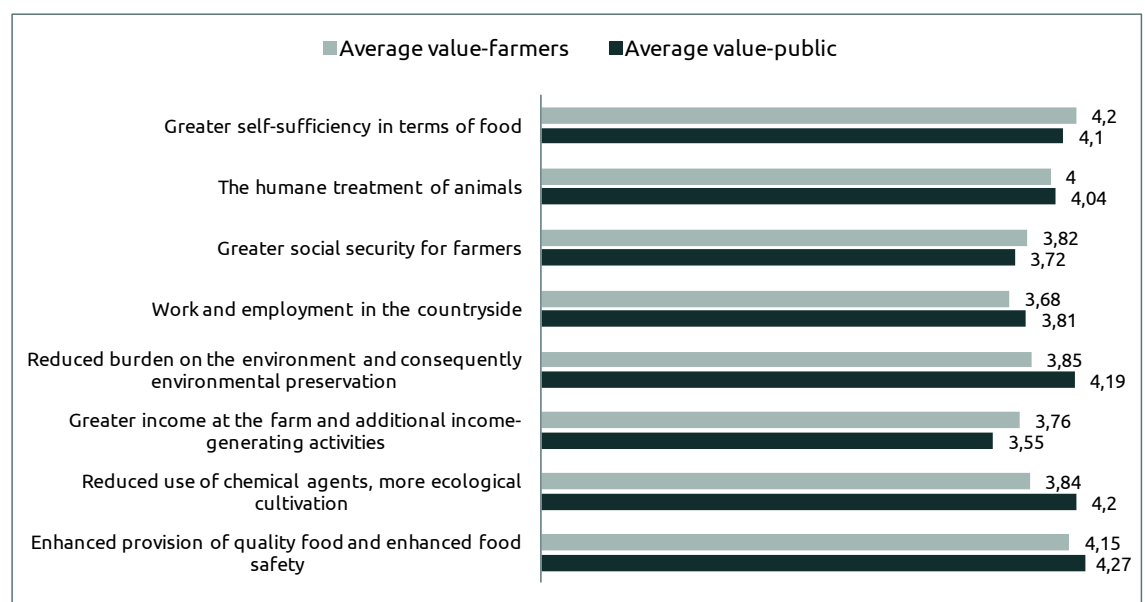

Table 2: Mann-Whitney test for statements about what best characterises sustainable agriculture

\begin{tabular}{|l|r|r|r|r|}
\hline & $\begin{array}{r}\text { Mann- } \\
\text { Whitney U }\end{array}$ & Wilcoxon W & Z & $\begin{array}{r}\text { Asymp. } \\
\text { Sig. } \\
\text { (2-tailed) }\end{array}$ \\
\hline $\begin{array}{l}\text { Enhanced provision of quality } \\
\text { food and enhanced food safety }\end{array}$ & 75865.000 & 128515.000 & -1.715 & .086 \\
\hline $\begin{array}{l}\text { Reduced use of chemical agents, } \\
\text { more ecological cultivation }\end{array}$ & 64993.500 & 117643.500 & -5.131 & .000 \\
\hline $\begin{array}{l}\text { Greater income at the farm and } \\
\text { additional income-generating } \\
\text { activities }\end{array}$ & 71279.000 & 197030.000 & -3.079 & .002 \\
\hline $\begin{array}{l}\text { Reduced burden on the } \\
\text { environment and consequently } \\
\text { environmental preservation }\end{array}$ & 68672.000 & 121322.000 & -3.974 & .000 \\
\hline $\begin{array}{l}\text { Work and employment in the } \\
\text { countryside }\end{array}$ & 78695.000 & 131345.000 & -.772 & .440 \\
\hline $\begin{array}{l}\text { Greater social security for } \\
\text { farmers }\end{array}$ & 75628.000 & 201379.000 & -1.726 & .084 \\
\hline $\begin{array}{l}\text { The humane treatment of } \\
\text { animals }\end{array}$ & 78208.500 & 130858.500 & -.934 & .350 \\
\hline $\begin{array}{l}\text { Greater self-sufficiency in terms } \\
\text { of food }\end{array}$ & 77986.000 & 203737.000 & -1.021 & .307 \\
\hline
\end{tabular}

The Mann-Whitney test confirmed that the responses given by the two group display a statistically significant difference in the case of only three of the statements (Table 2). For the statements »The reduced use of chemical agents, more ecological cultivation « and »Reduced burden on the environment, and consequently environmental preservation $(p=0.000)$ there was a greater degree of agreement among the public, while for the statement »Greater income at the farm and additional income-generating activities« $(p=0.002)$

58 Administration, Vol. X, No. 2/1012 
there was a greater degree of agreement among farmers. The general public attaches greater importance to the environmental determinants of sustainability, while farmers attach greater importance to economic determinants.

\subsection{The importance of sustainable agriculture compared to other areas of society and in terms of its functions}

The average mark for the importance of sustainable development in agriculture compared to other areas of society was very similar in both groups (Graph 2).

Graph 2: Importance of sustainable agriculture compared to other areas of society (on a scale of 1 to $5, \%$ )

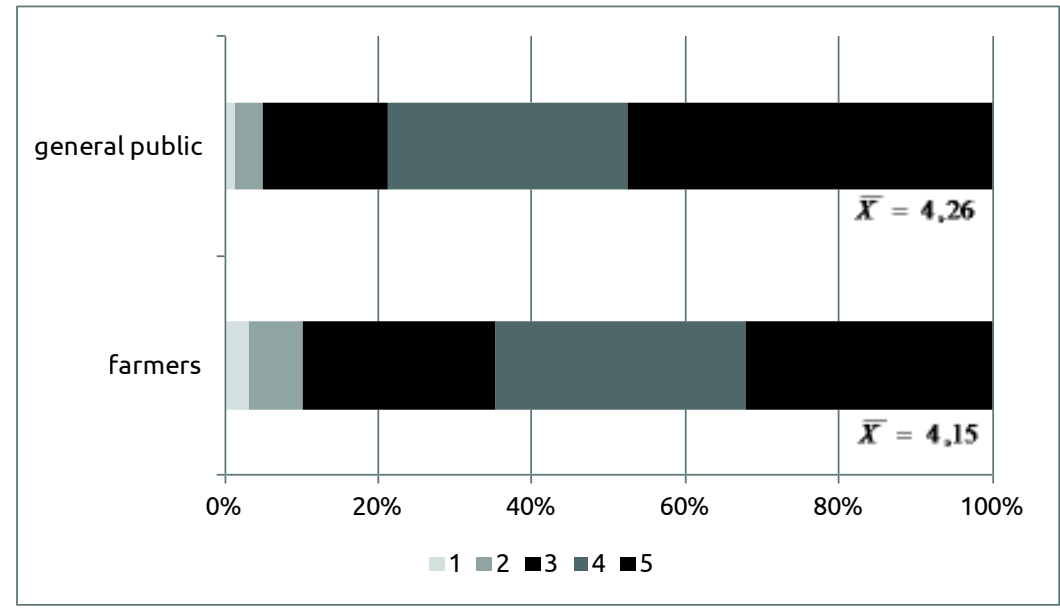

The results of the Mann-Whitney test were also not statistically significant $(p=0.147)$, which means that the public and farmers attach a similar degree of importance to sustainable agriculture compared to other areas of society.

A comparison of the average marks given to the importance of individual functions or objectives of sustainable agriculture (Graph 3) reveals that considerable differences appear in marks for the statements »Preserving the natural and cultural heritage", »The supervised use of fertilisers and phytopharmaceutical agents", "Stabilisation and an increase in income», »Reduced burden of agriculture on the environment» and "Protecting and maintaining the quality of the water, soil preservation«. The statement "Stabilisation and an increase in income received the highest marks among farmers, while statements that apply to the environment were given the highest marks by the general public. 
Maja Klun, Renata Slabe Erker

Graph 3: A comparison of average marks given by the public and by farmers for the importance of functions and objectives of agriculture

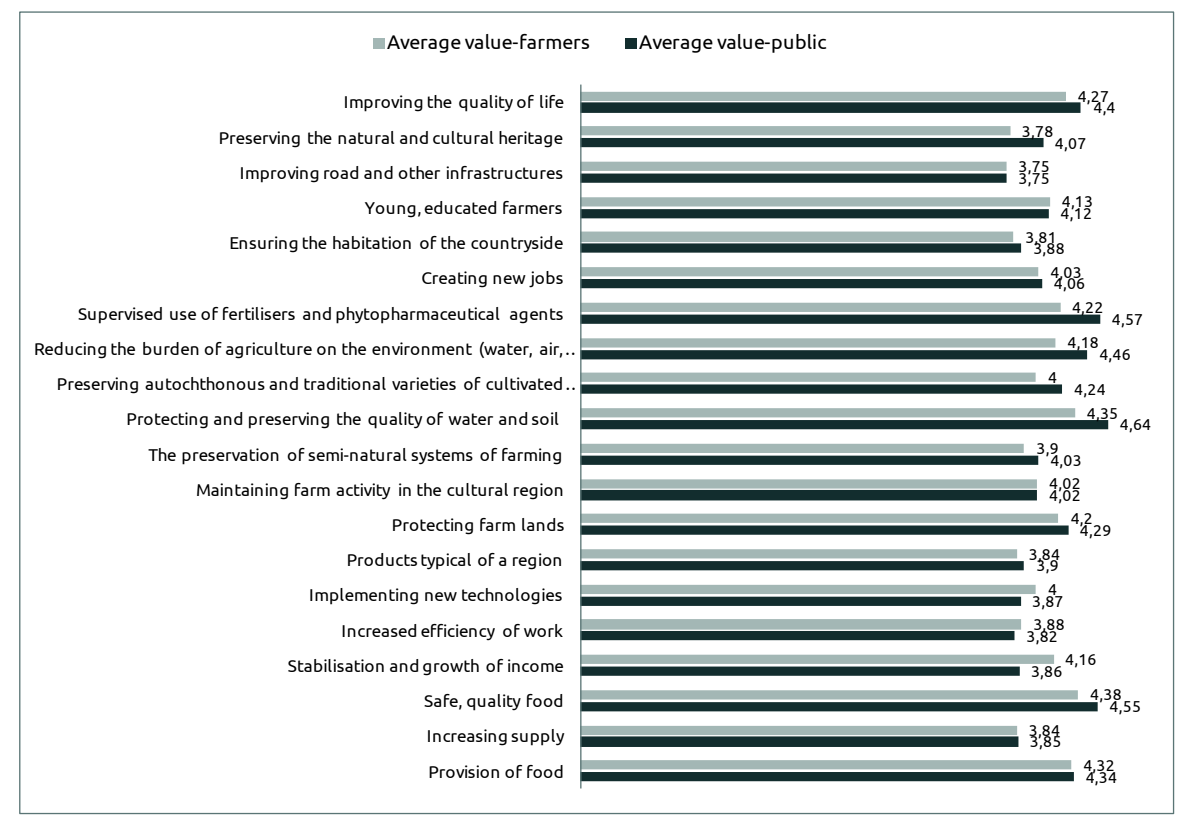

We also conducted a Mann-Whitney test for the statements listed above in order to determine whether a statistically significant difference could be noted between responses from the two groups of respondents. Table 3 shows that responses statistically differ between the groups for those statements for which a notable difference in average marks $(p \approx 0.000)$ has already been noted, and also for two more statements: "Safe, quality food", to which the public attaches greater importance, and »Preserving autochthonous and traditional varieties of cultivated plants and approaches to animal husbandry«, to which farmers attached greater importance. Again, it appears that the general public attaches somewhat greater value to the environmental dimension of sustainability, while farmers stress the economic dimension. This indicates the consistency of respondents in responding to the questions in the survey form.. 
Table 3: Mann-Whitney test for statements about the importance of individual functions or objectives of sustainable agriculture

\begin{tabular}{|c|c|c|c|c|}
\hline & $\begin{array}{r}\text { Mann- } \\
\text { Whitney U }\end{array}$ & Wilcoxon W & Z & $\begin{array}{l}\text { Asymp. } \\
\text { Sig. } \\
\text { (2-tailed) }\end{array}$ \\
\hline Provision of food & 79901.000 & 132551.000 & -.419 & .675 \\
\hline Increasing supply & 81012.500 & 133662.500 & -.047 & .962 \\
\hline Safe, quality food & 71695.500 & 124345.500 & -3.287 & .001 \\
\hline Stabilisation and growth of income & 64922.000 & 190673.000 & -5.139 & .000 \\
\hline Increased efficiency of work & 77218.000 & 202969.000 & -1.252 & .211 \\
\hline Implementing new technologies & 75143.000 & 200894.000 & -1.898 & .058 \\
\hline Products typical of a region & 78210.000 & 130860.000 & -.929 & .353 \\
\hline Protecting farm lands & 78377.500 & 131027.500 & -.906 & .365 \\
\hline $\begin{array}{l}\text { Maintaining farm activity in the } \\
\text { cultural region }\end{array}$ & 79998.500 & 132648.500 & -.371 & .711 \\
\hline $\begin{array}{l}\text { The preservation of semi-natural } \\
\text { systems of farming }\end{array}$ & 74820.500 & 127470.500 & -2.008 & .045 \\
\hline $\begin{array}{l}\text { Protecting and preserving the } \\
\text { quality of water and soil }\end{array}$ & 67057.500 & 119707.500 & -5.111 & .000 \\
\hline $\begin{array}{l}\text { Preserving autochthonous and } \\
\text { traditional varieties of cultivated } \\
\text { plants and approaches to animal } \\
\text { husbandry }\end{array}$ & 72578.000 & 125228.000 & -2.758 & .006 \\
\hline $\begin{array}{l}\text { Reducing the burden of agriculture } \\
\text { on the environment (water, air, } \\
\text { earth) }\end{array}$ & 68497.500 & 121147.500 & -4.212 & .000 \\
\hline $\begin{array}{l}\text { Supervised use of fertilisers and } \\
\text { phytopharmaceutical agents }\end{array}$ & 63570.500 & 116220.500 & -6.087 & .000 \\
\hline Creating new jobs & 81152.500 & 133802.500 & -.003 & .998 \\
\hline $\begin{array}{l}\text { Ensuring the habitation of the } \\
\text { countryside }\end{array}$ & 80810.000 & 133460.000 & -.111 & .912 \\
\hline Young, educated farmers & 80151.000 & 205902.000 & -.324 & .746 \\
\hline $\begin{array}{l}\text { Improving road and other } \\
\text { infrastructures }\end{array}$ & 79286.000 & 205037.000 & -.588 & .557 \\
\hline $\begin{array}{l}\text { Preserving the natural and cultural } \\
\text { heritage }\end{array}$ & 67952.500 & 120602.500 & -4.172 & .000 \\
\hline Improving the quality of life & 75733.500 & 128383.500 & -1.802 & .072 \\
\hline
\end{tabular}

\subsection{Perception of the development of agriculture in Slovenia and assessing reasons for this development}

Lastly, we were interested in people's views regarding how sustainable agriculture has developed over the past ten years (Table 4). Respondents were asked to assess development from three perspectives: the provision of food, the sustenance of farmers, and preserving the environment. A comparison of responses makes it clear that for the most part, both groups 
felt that development has taken a turn for the worse, in particular from the perspective of the sustenance of farmers. Regarding the provision of food, the percentage of the public that felt that the situation is deteriorating is lower, while the opposite is true for the aspect of environmental preservation. It is interesting that in both groups, the share of those who noted that development over the past ten years is taking a turn for the better or remains on the same level is roughly the same.

Table 4: Perceptions of the development of sustainable agriculture in the past ten years from three perspectives

\begin{tabular}{|l|r|r|r|r|r|r|}
\hline & \multicolumn{2}{|c|}{ Provision of food } & \multicolumn{2}{c|}{ Sustenance of farmers } & \multicolumn{2}{|c|}{$\begin{array}{c}\text { Environmental } \\
\text { preservation }\end{array}$} \\
\hline & Farmers \% & Public \% & Farmers \% & Public \% & Farmers \% & Public \% \\
\hline $\begin{array}{l}\text { Turn for the } \\
\text { better }\end{array}$ & 24.4 & 30.5 & 11.1 & 8.5 & 33.3 & 22.6 \\
\hline $\begin{array}{l}\text { Turn for the } \\
\text { worse }\end{array}$ & 54.6 & 46.1 & 74.1 & 71.3 & 41 & 54.3 \\
\hline $\begin{array}{l}\text { At the same } \\
\text { level }\end{array}$ & 21 & 23.4 & 14.8 & 20.2 & 25.6 & 23 \\
\hline
\end{tabular}

The Mann-Whitney test shows that in defining their opinion on whether the situation has taken a turn for the better or a turn for the worse in terms of the different aspects of the sustainable development of agriculture, responses do not statistically differ between the two groups. In both groups, the largest share consisted of those who felt that development has taken a turn for the worse.

In light of the focus of agricultural policy in the past ten years, farmers' perception of the development of agriculture seems very realistic. In this period, the state was supposed to invest funds primarily in the sustainable use of natural resources and regional preservation (approx. 80 million euros in 2010), with fewer funds going to enhancing the quality of life in the countryside (approx. 60 million euros in 2010) and the fewest going to improving the competitiveness of the agricultural foods sector (approx. 20 million euros in 2010). From 2000 to 2010, the share of total public funds for agricultural policy experienced a four-fold increase (Juvančič \& Slabe Erker, 2006). Economic data also confirms the poor state of affairs in the economic sector. Despite increases in agricultural production, a trend of declining GVA could be noted. In the 2000-2010 period, the share of GVA from agriculture in Slovenia fell by $0.8 \%$, and by an average of $1 \%$ for the EU-15 countries. From 2002 to 2009, the share of food expenditure among total expenditure fell in Slovenia by a little over $2 \%$, with the largest share of expenditure linked to imported food. Since 2005, the agricultural sector in Slovenia has not been commercially viable (the income-to-cost ratio is 0.9 or 0.8) (Eurostat, 2011).

On the other hand, the general public's pessimism about achieving the environmental sustainability of agriculture is exaggerated, contrasting as 
it does with favourable environmental-agricultural achievements and the current orientation of agricultural policy.

Respondents who said that development has taken a turn for the worse in terms of these two aspects were asked to state the reasons for their opinion (cf. Graph 4). The greatest differences in average marks were noted for the statement about the use of chemical agents, as the public felt that the increased use of these is a reason for the poor development of sustainable agriculture. The public also gave higher marks to statements linked to an increase in the overgrowth of arable land and migration to urban areas, while among farmers, a higher average mark was given to the statement about lower profits and lack of financial stimulus (subsidies) as a reason for the turn for the worse that in their opinion agricultural development has taken.

Once again, it appears the general public gives greater weight to environmental and spatial factors as reasons for the turn for the worse they feel agricultural development has taken, while farmers cite economic factors.

Graph 4: Comparison of average marks for statements from the public and farmers regarding why the development of sustainable agriculture has taken a turn for the worse over the past ten years

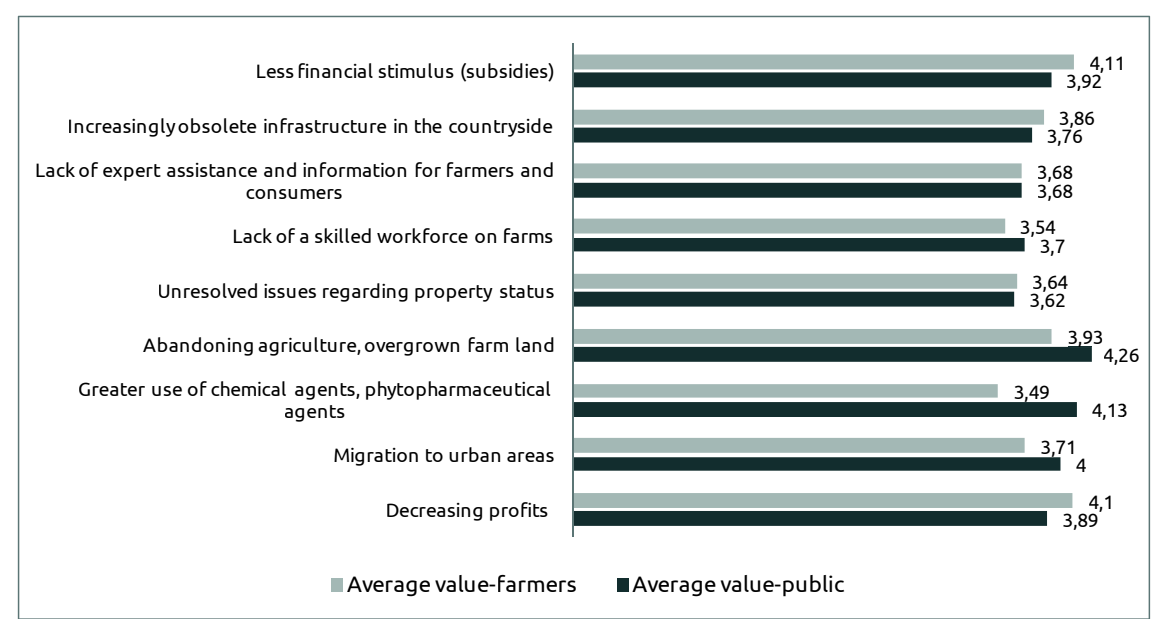

Here as well, a Mann-Whitney test was conducted for the individual statements. The results of the test (Table 5) make it clear that the differences between responses from the two groups to the statements discussed above are statistically significant. 
Maja Klun, Renata Slabe Erker

Table 5: Mann-Whitney test for statements about reasons why the development of sustainable agriculture has taken a turn for the worse

\begin{tabular}{|l|r|r|r|r|}
\hline & $\begin{array}{r}\text { Mann- } \\
\text { Whitney U }\end{array}$ & Wilcoxon W & Z & $\begin{array}{r}\text { Asymp. Sig. } \\
\text { (2-tailed) }\end{array}$ \\
\hline Decreasing profits & 22352.500 & 59208.500 & -2.833 & .005 \\
\hline Migration to urban areas & 22815.000 & 41536.000 & -2.469 & .014 \\
\hline $\begin{array}{l}\text { Greater use of chemical } \\
\text { agents, phytopharmaceutical } \\
\text { agents }\end{array}$ & 18366.000 & 37087.000 & -5.724 & .000 \\
\hline $\begin{array}{l}\text { Abandoning agriculture, } \\
\text { overgrown farm land }\end{array}$ & 22591.500 & 41312.500 & -2.688 & .007 \\
\hline $\begin{array}{l}\text { Unresolved issues regarding } \\
\text { property status }\end{array}$ & 25033.500 & 61889.500 & -.820 & .412 \\
\hline $\begin{array}{l}\text { Lack of a skilled workforce on } \\
\text { farms }\end{array}$ & 24447.000 & 43168.000 & -1.251 & .211 \\
\hline $\begin{array}{l}\text { Lack of expert assistance and } \\
\text { information for farmers and } \\
\text { consumers }\end{array}$ & 25640.000 & 62496.000 & -.375 & .707 \\
\hline $\begin{array}{l}\text { Increasingly obsolete } \\
\text { infrastructure in the } \\
\text { countryside }\end{array}$ & 24504.500 & 61360.500 & -1.210 & .226 \\
\hline $\begin{array}{l}\text { Less financial stimulus } \\
\text { (subsidies) }\end{array}$ & 22842.000 & 59698.000 & -2.459 & .014 \\
\hline
\end{tabular}

Graph 5: Comparison of average marks for statements from the public and farmers regarding why they feel the development of sustainable agriculture has taken a turn for the better over the past ten years

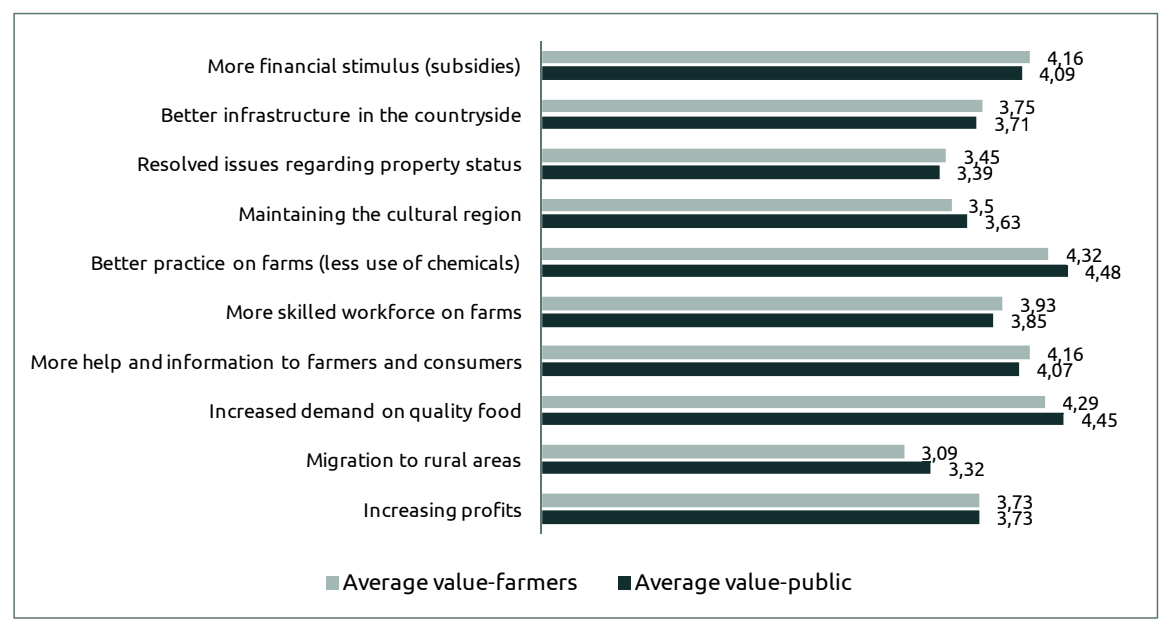

A greater degree of harmonisation between the responses from the two groups could be noted in reasons behind the view that development is taking a turn for the better (cf. Graph 5), as the average marks in the two groups are quite similar. The part of the public which felt that development is in

64 Administration, Vol. X, No. 2/1012 
fact headed in the right direction gives credit for this development, on the production side, to improved farming practices and, on the consumption side, to customers who demand quality, domestically produced foods. People attach little weight to migration to the countryside as a factor behind the perceived improvement in agricultural development. The public (especially the general public) is obviously very polarised in its perception of advances in the field of the environment.

The results of the Mann-Whitney test also show a relatively similar assessment of reasons between the two groups of respondents.

Taking into account data on the condition of the environment and healthy food, we feel it is safe to say that despite differences in the public's opinion and perceptions, both factors are changing for the better. This is also borne out by a cursory overview of certain data on the condition of the environment. Over the past ten years, for example, the so-called oxygen balance, that is the difference between intake and output of oxygen of arable land, has improved, from $101 \mathrm{~kg} \mathrm{~N} / \mathrm{ha}$ in 2003 to $64 \mathrm{~kg} \mathrm{~N} / \mathrm{ha}$ in 2007 (Eurostat, 2011). Average use of phytopharmaceutical agents in Slovenia in the period 2000-2007 was a little over $125 \mathrm{~kg}$ per hectare. Since 2000, the use of phytopharmaceutical agents has fallen: in 2007, it was 16\% lower than in 2002 (Statistical Office of the Republic of Slovenia, 2009). The sale of phytopharmaceutical agents in Slovenia in the period 2000-2005 decreased by approximately 5\% (Eurostat, 2011). The positive response of agricultural economies to agricultural policies which support the expansion of ecological agriculture has also grown from year to year. From 1999 to 2008, the area of land intended for ecological agriculture increased from 2,400 hectares to 29,836 hectares, from $0.5 \%$ to $6.1 \%$ of all arable lands in use (ARSO, 2009). Another piece of data which confirms that the state is devoting attention to the question of safe and quality food is the share of expenditure of research and development linked to food safety within the gross social product (GSP); at over $0.5 \%$, it is wholly comparable with the average for the EU-27 (0.53\%) (Eurostat, 2011).

\section{Conclusion}

Except on the declarative level, expert bases which would provide a wellargued demonstration of the level of sustainable orientation in agriculture and agricultural policy are not available. A similar deficit is to be noted in the area of research of support for this concept among the public; this was the focus of this article.

We studied the opinion of the general public and farmers about the importance of sustainable agriculture in Slovenia. It was determined that people feel that the sustainable development of agriculture is very important, and that the public places more of an emphasis on the environmental dimensions of sustainability, while farmers emphasise the social dimension of sustainability, with specific emphasis on their income situation. In the 
opinion of both target groups, sustainable agriculture is best characterised by the terms self-sufficiency in terms of food, safe food and quality food. This indicates a favourable prognosis for sales of domestically produced food in the future. That is why at the present, at a time when sustainable agricultural practices are in general not economically justifiable and citizens are already aware of the health and environmental benefits of quality, safe food (though this awareness has yet to be borne out by actual consumer habits), existing stimulus measures from the political sphere are very welcome. Here we have in mind stimulus on the production side, such as measures for encouraging domestic consumption, direct payments for extensive grazing systems and for dairy products in hilly areas, support for groups of manufacturers in disseminating information and accelerating sales of products included in food quality certification schemes (PRP - measure 133), and stimulus on the consumption side, such as programmes for disseminating information and promoting safe food.

People also attach a great deal of importance to environmental preservation, which could be achieved through a reduced burden on the environment and through the protection and preservation of quality (drinking) water and soil. This primarily implies the reduced use of chemical agents or the reduced unsupervised use of fertilisers and phytofarmaceutical agents and improved agricultural practices. Ecological agriculture fulfils all these demands. Measures taken by politics which impact this segment apply for the most part to measures for improving the environment and areas (agriculturalenvironmental payments and payments for areas with restrictive factors). This aspect is also being increasingly taken into account in practice; the public, on the other hand, fails to perceive this or is split in its perception of the situation. For this reason, positive information about developments in this field is urgently needed.

In the research project, we found that the public perceives that the sustainable development of agriculture in Slovenia is taking a turn for the worse in terms of the sustenance of farmers. While a considerable amount of financial assistance in the form of various subsidies is provided for farmers, some farmers meet with difficulty in obtaining this assistance and are therefore solely dependent on income generated through the sale of the food they produce. Economic data also confirms the poor state of affairs in this field. Statistically significant differences between the general public and farmers appeared precisely in understandings of sustainable advances in agriculture in the field of the environment. The general public is considerably polarised. On the one hand, a majority feel that development in the field of the environmental sustainability of agriculture is taking a turn for the worse, even though environmental-agricultural indicators paint a different picture, namely that the actual situation in this field has seen extraordinary advances and that in this regard Slovenia is comparable to other European countries. On the other hand, a large part of the general public (though not a 
majority) credits environmental factors with bringing about improvements in development. By comparison, the perceptions of farmers are nearer to reality and farmers are well aware of shortcomings in the fields of quality of life and farmers' poor income situation. This finding is a call for the provision of wellbalanced, objective information to the public.

The idea of sustainable agriculture has been a subject of debate for quite some time. Certain movements in this direction can be noted; however, the extent of these developments is not what it should be. The share of those who purchase ecologically processed domestically produced food in Slovenia remains low. The own sale by farmers of agricultural products in food markets in 2010 amounted to little over 3\% of the total GVA of agriculture (Statistical Office of the Republic of Slovenia, 2011). With such weak support for sustainable agriculture from consumers, it is difficult, even with assistance from the state, to ensure the economic and social security of the farmer. It is important that these matters not only be discussed on the theoretical level; attempts to force changes in peoples' behaviour must not be limited to rules and regulations, but must also seek to change their convictions and values in order to get them to change and ultimately abandon currently dominant patterns of life and behaviour. This is a long-term process, and as such would be easiest to implement through the use of a suitable system of education. People will change their patterns of behaviour if they are appropriately motivated, informed and notified. An exemplary step in this direction could be guaranteed markets for fruits and vegetables that spoil quickly (the public sector, for example).

The focus of the research was on personal opinions: what people think about an individual thing or an individual function of sustainable agricultural development. A quantitative measure of these views can only be provided through the use of public opinion surveys, which, as we know, are not very objective. Additionally, personal opinions do not always express the current situation; in other words, perceptions can deviate from reality. That is why we confronted the results of our research with the actual situation. We could have improved our research by conducting the surveys on a larger statistical sample, as this would have provided a basis for stating that the conclusions and opinions of individuals are in reality those deduced in the research. It would be interesting if, in further research projects, we were to study what impacts and shapes people's opinions. We could have focused on personal values or on the effects of various media on individuals' opinions, which would have enabled us to identify factors which need to be addressed in efforts to change or strengthen awareness of sustainability, production practices, consumer habits and/or food consumption patterns. We believe that in this manner it would be possible to achieve synergetic effects in the economic, social and environmental fields of development. 
Maja Klun, Renata Slabe Erker

Maja Klun, PhD is associate professor at Faculty of Administration. Her main research fields are taxation, performance budgeting and performance measurement in public sector.

Renata Slabe Erker, PhD is from 1995 employed at the Institute for Economic Research, Ljubljana. As a senior researcher, she has actively taken part in and coordinated a number of research projects in the fields of environmental economics the economics of natural preservation and sustainable development.

68 Administration, Vol. X, No. 2/1012 


\section{References}

- Aerni, P. (2009). What is sustainable agriculture? Empirical evidence of diverging views in Switzerland and New Zealand. Ecological Economics (68), 1872-1882.

- Alonge J. A. \& Martin, R. A. (1995). Assessment of the Adoption of Sustainable Agriculture Practices: Implications for Agricultural Education. Journal of Agricultural Education (36), 34-42.

- Bhutto, A. W., \& Bazmi, A. A. (2007). Sustainable agriculture and eradication of poverty in Pakistan. Natural Resources Forum (31), 253-262.

- European Commission (2012). Kmetijstvo in razvoj podeželja. Skupna kmetijska politika na dlani. [Agriculture and the Development of the Countryside. Common Agricultural Policy at a Glance]. Retrieved 20. 2. 2012, from http://ec.europa.eu/agriculture/publi/capexplained/cap_sl.pdf (5. 2. 2012).

- Eurostat (2011). Economic Accounts for Agriculture, EC.

- Hosseini, S. J. F., Mohammadi F. \& Mirdamadi, S. M. (2011). Factors affecting environmental, economic and social aspects of sustainable agriculture in Iran. African Journal of Agricultural Research (6), 451-457.

- Ikerd, J. E. (1994). Systems Research in Sustainable Agriculture: Economics, Ecology, and Quality of Life. American Journal of Agricultural Economics (76), 1271.

- Juvančič, L. \& Slabe Erker, R. (2006). Policy practice vs. public Perception: does the support for multifunctional agriculture in Slovenia deliver the right thing? Journal of Central European Agriculture (7), 565-570.

- Mann, H. B. \& Whitney, D. R. (1947). On a test of whether one of two random variables is stochastically larger than the other. Annals of Matematical Statistics (18), 50-60.

- Napier, T. L., Thraen, C. S., Gore, A., \& Goe, W. R. (1984). Factors affecting adoption of conventional and conservation tillage practices in Ohio. Journal of Soil and Water Conservation (39), 205-209.

- Plut, D. (2004). Zeleni planet? Prebivalstvo, energija in okolje v 21. stoletju. [Green Planet? Population, Energy and the Environment in the 21st Century]. Ljubljana: Didakta.

- Public Law 101-624, Title XVI, Subtitle A, Section 1683

- Rahman, S. (2003). Environmental impacts of modern agricultural technology diffusion in Bangladesh: An analysis of farmers' perceptions and their determinants. Journal of Environmental Management (68), 183-191.

- Rao, N. H. \& Rogers, P. P. (2006). Assessment of agricultural sustainability. Current Science (91), 439-448.

- Rao, P. P. \& Hall, A. J. (2003). Importance of crop-livestock system in India and farmers' perceptions of fodder quality in coarse cereals. Field Crops Research (84), 189-198.

- Slovenian Environment Agency (2009). Indicators of the Environment in Slovenia. Ljubljana: Ministry of Agriculture and the Environment of the Republic of Slovenia.

- Special Eurobarometer (2008). Europeans, Agriculture and the Common Agricultural Policy. European Commission, Brussels. Pridobljeno 20. 2. 2012, s http://ec.europa.eu/agriculture/survey/2008/fullreport_en.pdf.

- Statistical Office of the Republic of Slovenia. SI-STAT data portal. Retrieved in December 2011, from http://pxweb.stat.si/pxweb/Dialog/statfile2.asp 
Maja Klun, Renata Slabe Erker

- Swanson, L., Camboni, S. \& Napier, T. (1986). Barriers to adoption of soil conservation practices on farms. In Lovejoy, S. \& Napier, T. (Eds.). Conserving soils: Insights from socioeconomic research. Ankeny, lowa: Soil Conservation Society of America.

- Tathdil F. F., Boz I. \& Tatlidil, H. (2009). Farmers' perception of sustainable agriculture and its determinants: a case study in Kahramanmaras province of Turkey. Environment, Development and Sustainability (11), 1091-1106.

- Taylor, D., Mohamed, Z., Shamsudin, M., Mohayidin, M., \& Chiew, E. (1993). Creating a farmer sustainability index: A Malaysian case study. American Journal of Alternative Agriculture (8), 175-184.

- Zakon o kmetijstvu (ZKme-1). Ur. list RS, št. 45/2008. [Agricultural Act of the Republic of Slovenia (ZKme-1). Official Gazette of the Republic of Slovenia, no. 45/2008.] 